\author{
V.M. Kvasnytsya, L.V. Shumlyanskyy \\ M.P. Semenenko Institute of Geochemistry, Mineralogy \\ and Ore Formation of the NAS of Ukraine \\ 34, Acad. Palladin Ave., Kyiv, Ukraine, 03142 \\ E-mail: vmkvas@hotmail.com; lshumlyanskyy@yahoo.com
}

\title{
NATIVE GOLD AND DIAMONDS FROM THE PALAEOPROTEROZOIC TERRIGENOUS ROCKS OF THE BILOKOROVYCHI BASIN, NORTH-WESTERN REGION OF THE UKRAINIAN SHIELD
}

The Bilokorovychi basin is located in the North-Western region of the Ukrainian Shield. It is a 2 to $6 \mathrm{~km}$ wide and $22 \mathrm{~km}$ long weakly deformed and metamorphosed volcano-sedimentary basin that was formed between c. 1.98 and $1.80 \mathrm{Ga}$. The Palaeoproterozoic conglomerates and sandstones of the basin host unusual association of native gold and diamond. Native gold from conglomerates is variable in terms of its morphology and chemical composition. Massive fine anhedral gold grains prevail. Grains of the porous gold and grains with numerous autoepitaxic overgrowths of the secondary gold are also common. The microscale overgrown crystals are very variable in terms of their morphology and range from crystallographically undefined grains to ideal octahedrons and their intergrowths, including twins, fivelings, and skeletal octahedrons. Chemical composition ranges from pure gold to medium-grade, silvery, and cuprous gold. Pure gold prevails. Gold and quartz intergrowths are common. Several types of native gold were distinguished according to the mineral assemblages and to the morphology and chemical composition of gold crystals. These types are detrital gold which is rather rare, and a prevailing authigenic gold including biogenic and secondary gold. Diamonds from conglomerates of the Bilokorovychi basin are the oldest so far found in Europe. In terms of the crystal morphology, carbon isotope systematics, and the concentration and state of nitrogen admixture, Bilokorovychi diamonds resemble mantle-derived diamonds from kimberlites and lamproites. In terms of the degree of nitrogen aggregation, some of the Bilokorovychi diamonds are similar to the Archaean diamonds which crystallized in quiet conditions and a low thermal gradient in the mantle. Rest of the studied diamonds, according to the degree of nitrogen aggregation, had grown at higher temperatures which are more common for the Proterozoic diamonds. An average nitrogen concentration evidence that the studied diamonds are closer to the mantle eclogitic assemblage than to the peridotitic assemblage. The heavy roundness of diamond crystals indicates their prolonged transportation from the bedrock source to the site of deposition. The bedrock source may be represented by kimberlite, lamproite or other rock with the age exceeding or close to $1800 \mathrm{Ma}$. The most favorable model of the Bilokorovychi diamonds origin is a subduction model. Available data indicate that the North-Western region of the Ukrainian Shield was formed between c. 2150 and 1980 Ma due to continuous subduction of the oceanic lithosphere and gradual accretion of the newly-formed continental crust. A large-scale magmatic event that started at c. 1815 Ma could be a suitable transporter of the mantle-derived material, including diamonds, to the surface.

Keywords: native gold, diamond, the Bilokorovychi basin, the Palaeoproterozoic conglomerates, the Ukrainian Shield.

Introduction. The Bilokorovychi sedimentary basin is relatively small and located in the North-Western region of the Ukrainian Shield. It attracts attention due to its geological setting and to the unusual association of native gold and diamond that was found in its rocks. Numerous grains of native gold and 90 diamond crystals were found in the Bilokorovychi metasedimentary rocks at the early 1980s [36]. Among those diamond crystals, 42 were

(C) V.M. KVASNYTSYA, L.V. SHUMLYANSKYY, 2018 found in conglomerates of the lower part of the Bilokorovychi Suite (see below), 2 were revealed in basal sandstones of the same suite, 45 occurred in the sandstones of the upper part of the Bilokorovychi Suite, and 1 crystal was found in sandstone of the Tovkachi Suite. The weight of the largest diamond is $22.8 \mathrm{mg}$. Most of these diamonds and particularly large grains were found in the southern part of the Bilokorovychi basin. In this communication we present data regarding native gold and diamond mineralization in the Bilokorovychi basin and discuss their origin. 
Geology of the Bilokorovychi basin (geological setting, composition, and age of the rocks). Geological setting. The Bilokorovychi basin is 2 to $6 \mathrm{~km}$ wide and $22 \mathrm{~km}$ long volcano-sedimentary basin filled with rocks of the Topilnya Series [27, 29] (Fig. 1). The Topilnya Series rocks are generally gently sloping $\left(15-30^{\circ}\right)$ and weakly deformed. Rocks are weakly metamorphosed and cut by veins and dykes of felsic and mafic compositions [33]. The Topilnya Series unconformably rests on the $2150-1980 \mathrm{Ma}$ $[15,37]$ crystalline basement composed of gneisses of the Teteriv Series, and granites of the Zhytomyr and Osnitsk complexes.

Stratigraphy of the Topilnya Series. The thickness of the Topilnya Series is up to $1100 \mathrm{~m}$; it is subdivided into the lower Bilokorovychi and the upper Ozeryany Suites [29]. The lower part of the Bilokorovychi Suite reaches $69 \mathrm{~m}$ in thickness and comprises siltstone, conglomerate, gravel, and sandstone that

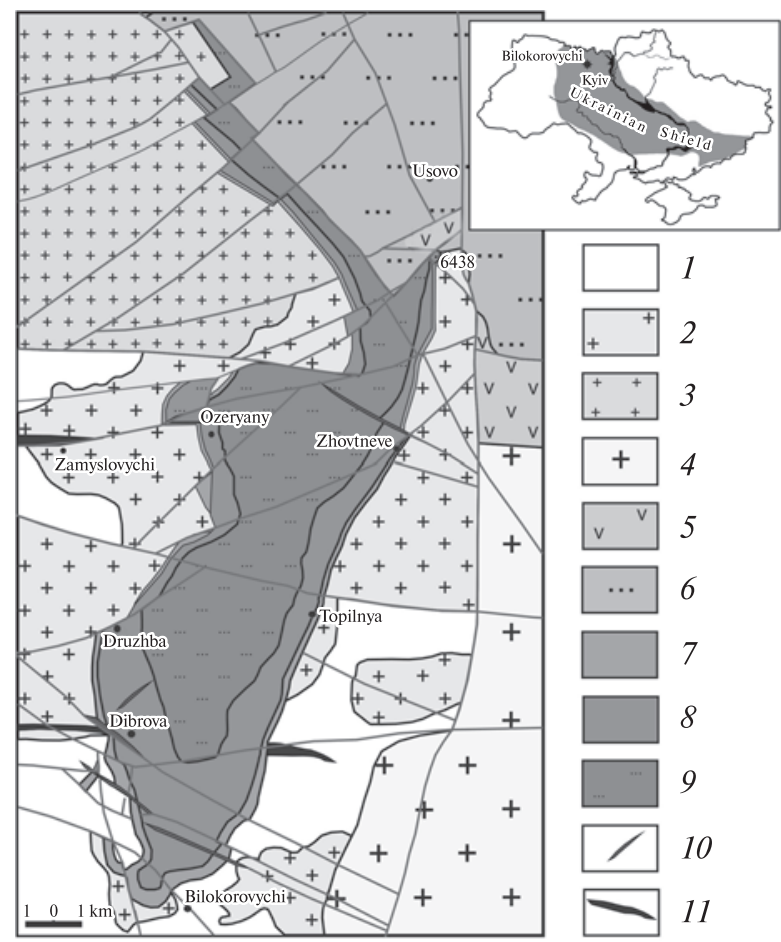

Fig. 1. Geological position and schematic geological map of the Bilokorovychi basin, simplified after Kostenko (2011) [33]: 1 - metamorphic rocks of the Horodska Suite of the Teteriv Series; 2 - granitoids of the Zhytomyr and Sheremetiv Complexes; 3 - granites of the Osnitsk and Perga Complexes; 4 - granites of the Korosten Complex; 5 - effusive rocks of the Zbranki Suite; $6-$ terrigenous rocks of the Tovkachi Suite, Topilnya Series; 7 and $8-$ Bilokorovychi Suite ( 7 - Lower Bilokorovychi Subsuite, 8- Upper Bilokorovychi Subsuite); 9 - Ozeryany Suite; 10 - dolerite and gabbronorite of the post-Ovruch dyke complex; and 11 - ancient (pre-Bilokorovychi) gabbro and gabbro-dolerite form three rhythms and can be traced throughout in the basin. Conglomerates of the lower part of the Suite are multi-colored rocks made of the wellrounded pebbles and boulders of the spherical or elliptical shape that can reach $10-12 \mathrm{~cm}$ in size (Fig. 2). Pebbles are mainly made of quartz; the bright red, brown or dark-gray jasper pebbles are less common. Pebbles made of reddish-brown and light-gray quartzite, brown and dark-gray felsite, metarhyolite (quartz porphyry) are also present. Rare types of pebbles are represented by white sericite and muscovite schists, and albite-tourmaline and quartz-tourmaline greisen. Two thin (up to $6.5 \mathrm{~m}$ ) basaltic flows are known in the lower part of the sedimentary sequence $[33,38]$.

The upper part of the Bilokorovychi Suite has a thickness of $250-320 \mathrm{~m}$ and it spreads over the whole basin and crops out in several open pits. These sediments include quartzite and prevailing sandstones with well-developed horizontal and cross-bedding. The detrital material is represented by angular, semi-rounded and rounded quartz grains. Fragments of feldspar, muscovite, biotite, zircon, ilmenite, and tourmaline crystals are also present. Rocky fragments of metarhyolite, argillite, siliceous rocks and sandstone are rare.

Sandstones of the Bilokorovychi Suite are gradually replaced upwards by mudstones, siltstones, sericite-quartz schists and feldspar-quartz sandstones of the Ozeryany Suite. Thin (1.7 to $25 \mathrm{~m}$ ) basaltic flows are also present in the lower part of the suite. Terrigenous rocks of the Ozeryany Suite contain very fine acute-angled fragments of quartz, fresh plagioclase and microcline. The maximum thickness of the Suite is $567 \mathrm{~m} \mathrm{[33].} \mathrm{The} \mathrm{sediments}$ are cut by series of dykes, veins and sheet-like igneous bodies of mafic and felsic compositions. At contacts with the intrusions sedimentary rocks are thermally metamorphosed and transformed into hornfelses and schists.

Age of the Topilnya Series. Several attempts to date rocks of the Bilokorovychi basin were undertaken. According to results of K-Ar dating [27], chlorite-sericite schists were formed at 1300$1480 \mathrm{Ma}$, while dykes and metabasalt flows crystallized at 1000-1640 Ma. Gorokhov et al. (1981) [6] employed $\mathrm{Rb}-\mathrm{Sr}$ isochron method to date the age of metagenetic alteration of the Ozeryany Suite schists at $1574 \pm 31 \mathrm{Ma}$, whereas U-Pb zircon dating indicated that WE-trending dolerite dykes intruded deposits of the Bilokorovychi basin at $1799 \pm 10 \mathrm{Ma}$ [39], and rhyolite dykes were emplaced at $1781 \pm 3 \mathrm{Ma}$ [1]. Shumlyanskyy et al. (2015) 
[18] studied $\mathrm{U}-\mathrm{Pb}$ age and $\mathrm{Hf}$ isotope compositions in detrital zircons from sandstone of the Bilokorovychi Suite. The studied zircon grains have a wide spectrum of ages that vary from $3530 \pm 17$ to 2031 $\pm 7 \mathrm{Ma}$, whereas the majority of zircons fall into the 2200-2000 Ma age interval and have positive $\varepsilon \mathrm{Hf}_{\mathrm{T}}$ values, indicating the juvenile nature of their source rocks. In terms of their age and $\mathrm{Hf}$ isotope compositions, most of the zircons from the Bilokorovychi sandstones resemble those from granites of the Zhytomyr Complex and from metamorphic rocks of the Teteriv Series. Older zircons ( $>2500 \mathrm{Ma}$ ) often have negative $\varepsilon \mathrm{Hf}_{\mathrm{T}}$ values. Such zircons are absent in the local rocks and were probably derived from Archaean rocks of the Dniester-Bug Domain.

Summarizing, the geological relationships and results of $\mathrm{U}-\mathrm{Pb}$ isotope investigations of zircon indicate a Palaeoproterozoic age of the sedimentary rocks of the Bilokorovychi basin. They were deposited between c. 1980 Ma (age of the underlying eroded rocks of the Osnitsk Complex) and $1800 \mathrm{Ma}$ (age of the Bilokorovychi dyke).

Samples and methods. Samples collection. Diamond and native gold crystals were provided over the long period of time by the Zhytomyr geological enterprise. Sampled rocks were collected at outcrops and prospecting shafts. Isolation of mineral fractions was done employing conventional methods that included crushing and grinding of the rock samples, and further gravitational and electromagnetic separation and flotation. Diamond and native gold crystals were picked up manually under the binocular microscope.

Native gold. Morphology and chemical composition of $>150$ native gold grains isolated from conglomerates in the south-western part of the Bilokorovychi basin have been studied. Those grains were yellow in color, but some of them had copper tint. Their size varied from 0.2 to $2-3 \mathrm{~mm}$, and a few of them were up to $5 \mathrm{~mm}$ in size. Morphology and chemical composition of native gold were determined using a JSM-6700F field emission scanning electron microscope equipped with a JED-2300 energy-dispersive spectrometer (JEOL, Japan) at the M.P. Semenenko Institute of Geochemistry, Mineralogy and Ore Formation, National Academy of Science of Ukraine. The conductive coating of gold grains by carbon was applied. The SEM-EDS method was applied both for identification of native gold and various mineral intergrowths, and for determination of the chemical composition of gold. Operating conditions were as follows: $20 \mathrm{kV}$ accelerating voltage, $0.6 \mathrm{nA}$ beam

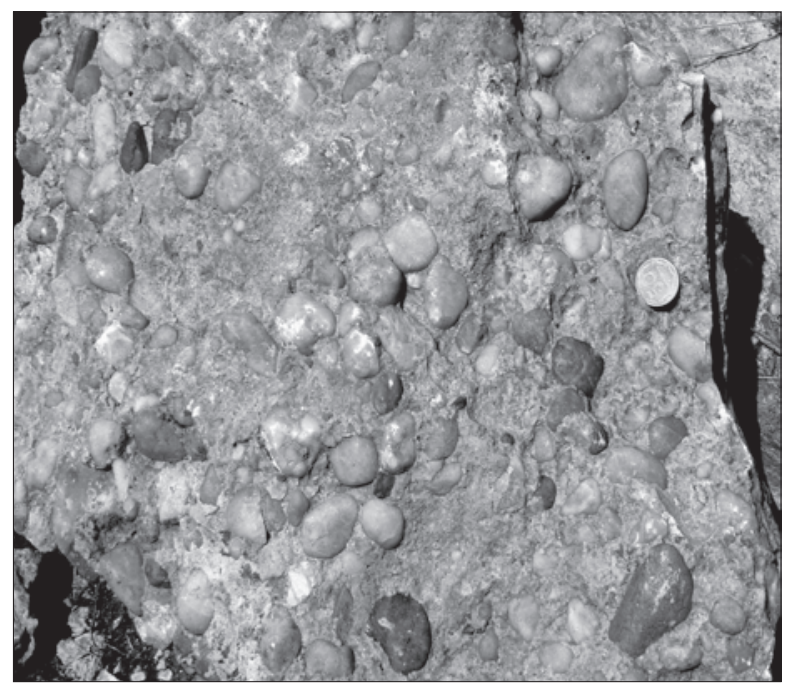

Fig. 2. Conglomerate of the Lower Bilokorovychi Subsuite

current, $2 \mu \mathrm{m}$ beam size and a counting time of 60 seconds for one analysis. Pure $\mathrm{Si}, \mathrm{Ti}, \mathrm{Al}, \mathrm{Fe}, \mathrm{Cr}$, $\mathrm{Cu}, \mathrm{W}, \mathrm{Au}, \mathrm{Ag}$, pyrite and synthetic $\mathrm{Na}_{3} \mathrm{AlF}_{6}, \mathrm{KCl}$, $\mathrm{MgO}, \mathrm{CaF}_{2}$ were used for calibration. Raw counts were corrected for matrix effects applying the ZAF algorithm implemented by JEOL.

Diamond. We have studied the morphology of 20 diamond crystals isolated from conglomerates of the south-western part of the Bilokorovychi basin. This study was carried out in the M.P. Semenenko Institute of Geochemistry, Mineralogy and Ore Formation employing an electron microscope JSM 6700F. The conductive coating of diamond crystals by carbon was applied. Most of the crystals were less than $1 \mathrm{~mm}$ in size; the largest crystal was $3.25 \mathrm{~mm}$ in size. The infrared spectroscopy was applied for investigations of 14 diamond crystals from conglomerates, and of a single diamond crystal that has been isolated from Quaternary sediments near Zubkovychi village, some $20 \mathrm{~km}$ southwestward to the Bilokorovychi basin. In terms of morphology, these crystals were represented by octahedrons and their twins, cubes, crystals with a combination of forms $\{100\}+$ $+\{110\}+\{111\}$, dodecahedrons, one rounded crystal, and crystal fragments. Infrared spectra of eleven microdiamonds in the optical range 600$4000 \mathrm{~cm}^{-1}$ were obtained with use of the Fourier spectrometer Bruker IFS-66 at the German Research Centre for Geosciences, Potsdam. The resolution of the spectrometer is $2 \mathrm{~cm}^{-1}$. Diamonds were not subjected to mechanical or any other kind of destructive treatment.

Results. Native gold. Morphology. Most of the gold grains are anhedral due to crystallization in 

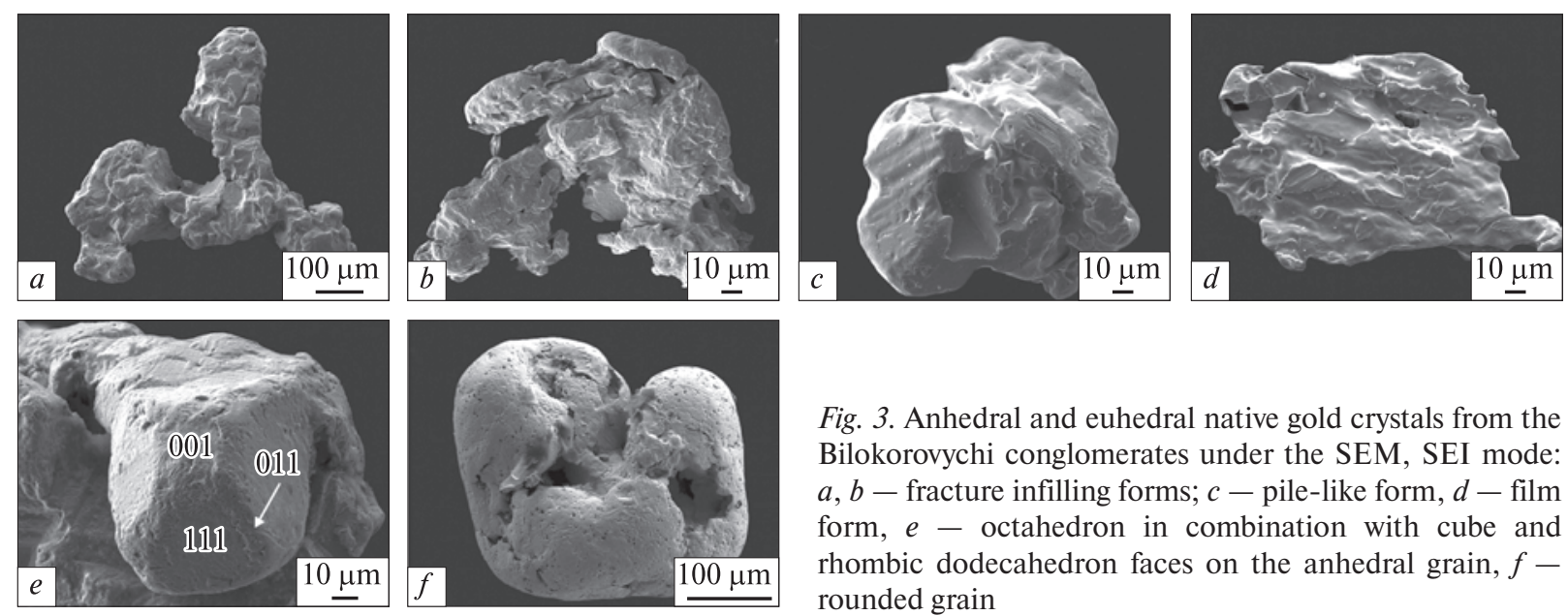

Fig. 3. Anhedral and euhedral native gold crystals from the Bilokorovychi conglomerates under the SEM, SEI mode: $a, b$ - fracture infilling forms; $c-$ pile-like form, $d-$ film form, $e$ - octahedron in combination with cube and rhombic dodecahedron faces on the anhedral grain, $f-$ rounded grain
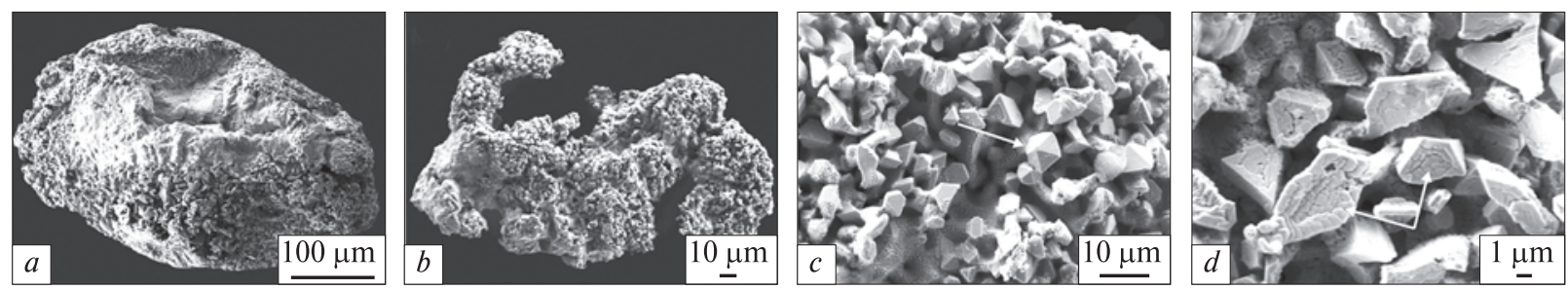

Fig. 4. Micro-polyhedrons of secondary native gold on primary gold grains from the Bilokorovychi conglomerates under the SEM, SEI mode: $a, b$ - the overgrowths of secondary gold on the primary native gold, $c$ - secondary gold, octahedrons and complex twin of octahedrons after (111) (the twin is indicated by the arrow), $d$ - secondary gold, skeletal octahedrons

microcaves and fractures that controlled their shape. They occur as massive lump-shaped grains, films, plates and wires (Fig. 3). The ball-shaped grains ornamented by micro-pores and the continuous balls with signs of rounding represent other morphological types of this mineral. Gold grains complicated by autoepitaxial overgrowths represented by the irregularly-shaped microcrystals and polyhedra are quite common (Fig. 4). These overgrowths may cover gold grains in whole or in part. We consider the autoepitaxial overgrowths as secondary gold, which has a characteristic appearance (micro-sized imperfect crystals and polyhedra, filamentary overgrowth, dendrites etc.), earthy or collomorphic structure of fine-grained aggregates, and significant variability of crystal chemistry.

Crystallography. Octahedron is the main variety of the growth form for microcrystals of both primary and secondary gold in the Bilokorovychi basin (Figs. 3 and 4). However, geometrical forms of the secondary gold polyhedra are especially diverse. These are well-shaped octahedrons and their flattened along the triple axis varieties (triangular plates), skeletal octahedrons, twins and fivelings of octahedrons in the (111) plane (Fig. 4). The secondary gold also occurs as thread-like forms and grown on the (111) plane layers which have formed the almost ideal octahedrons on the endpoint of the thread. A clear geometrically expressed autoepitaxial growth is typical for secondary gold.

Topography of the gold surface. There are several main types of the native gold surface in the Bilokorovychi conglomerates: typical for primary gold the large-block surface; typical for the sites of the secondary gold nucleation the fine-block surface; the porous surface that prevails on the spherical gold grains; and typical for secondary gold the spongy surface.

Chemical composition. Silver and copper are the major admixtures in native gold from the Bilokorovychi conglomerates (Fig. 5), whereas many of the gold crystals contain $\mathrm{Fe}$ (up to $3.5 \%$ ), and some of them contain a small amount of $\mathrm{Ni}$ and $\mathrm{Ti}$. Up to $85 \%$ of the gold crystals contain some $\mathrm{Ag}$, up to $50 \%$ of them contain $\mathrm{Cu}$, and $44 \%$ of the crystals contain both $\mathrm{Cu}$ and $\mathrm{Ag}$. Concentration of these elements is very variable. Most of the gold grains contain $1-5 \%$ of $\mathrm{Ag}$, and few of them contain $6-15 \%$ of Ag. Very few grains contain over $21 \%$ and even $40-44 \%$ of $\mathrm{Ag}$. Copper has a similar distribution: over the half of gold grains contains from 1 to $5 \%$ of $\mathrm{Cu}$, less than half grains contain 
$6-10 \%$ of $\mathrm{Cu}$, and few grains contain from 11 to $43 \%$ of $\mathrm{Cu}$. There is no apparent relationship between gold morphology and chemical composition, whereas there is a tendency for $\mathrm{Cu}$ enrichment in the gold grains having secondary overgrowths.

Mineral assemblages of native gold. Intergrowths of gold and quartz are the most common. Very fine inclusions of quartz were found in gold, whereas inclusions of gold in massive quartz crystals are even more common (Fig. 6). Microcrystals of native tungsten were found in a few grains of native gold that had secondary gold overgrowths (Fig. 6). Tungsten microcrystals are found in association with imperfectly to perfectly faceted overgrown microcrystals of secondary gold and often grow over them. Tungsten is present as individual scattered grains with sizes from 2 to $10 \mu \mathrm{m}$, or forms groups of 2-3 crystals. Gold that hosts tungsten overgrowths is relatively pure and contains up to $2-7 \% \mathrm{Ag}$ and $1.5-8 \% \mathrm{Cu}$. Tungsten microcrystals form almost ideal octahedrons or combinations of octahedron and cube. Most of the tungsten octahedrons are flattened along the triple axis; the flattening plane is more or less parallel to the surface of the gold grain over which it is grown. Some overgrowths of the secondary gold on tungsten crystals were also noticed. Tungsten crystals are free from impurities; a small amount of $\mathrm{Cr}$ (up to $0.16 \%$ ) was found in rare cases.

Chlorite, mica, kalsilite (Fig. 6), chalcosine, native copper and copper carbonates also occur as

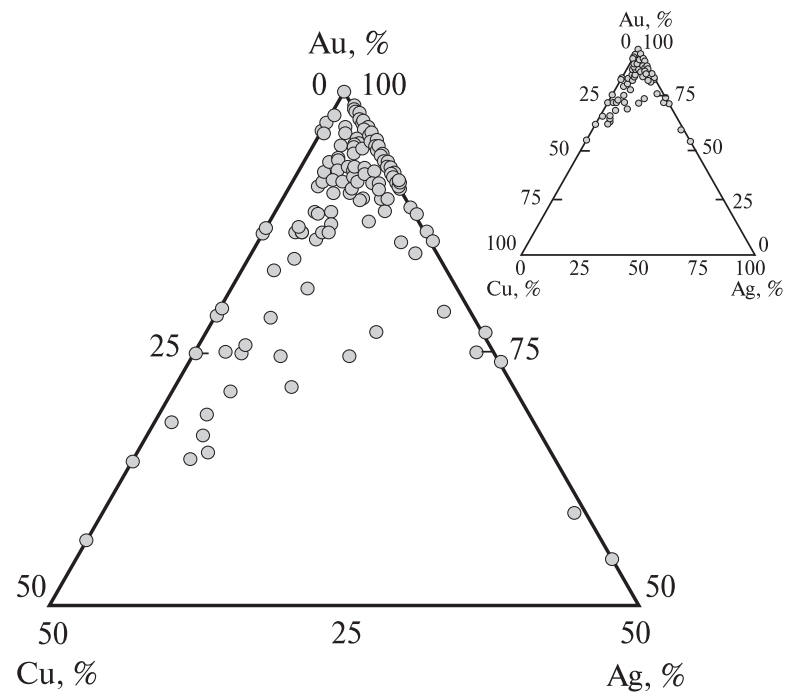

Fig. 5. Chemical composition of native gold from the Bilokorovychi conglomerates [32]

intergrowths with native gold. Aggregates of native gold with chlorite and mica are rather widespread and probably correspond to the mineral composition of the conglomerate matrix, whereas chalcosine and copper carbonates belong to the latest mineral assemblage.

Diamond. Crystal morphology. Diamonds range in size from 0.1 to $3.25 \mathrm{~mm}$. Colorless and yellowish octahedral crystals prevail, while colorless dodecahedron and grey cuboctahedron are less common, and colored cubic crystals are rare (Fig. 7).
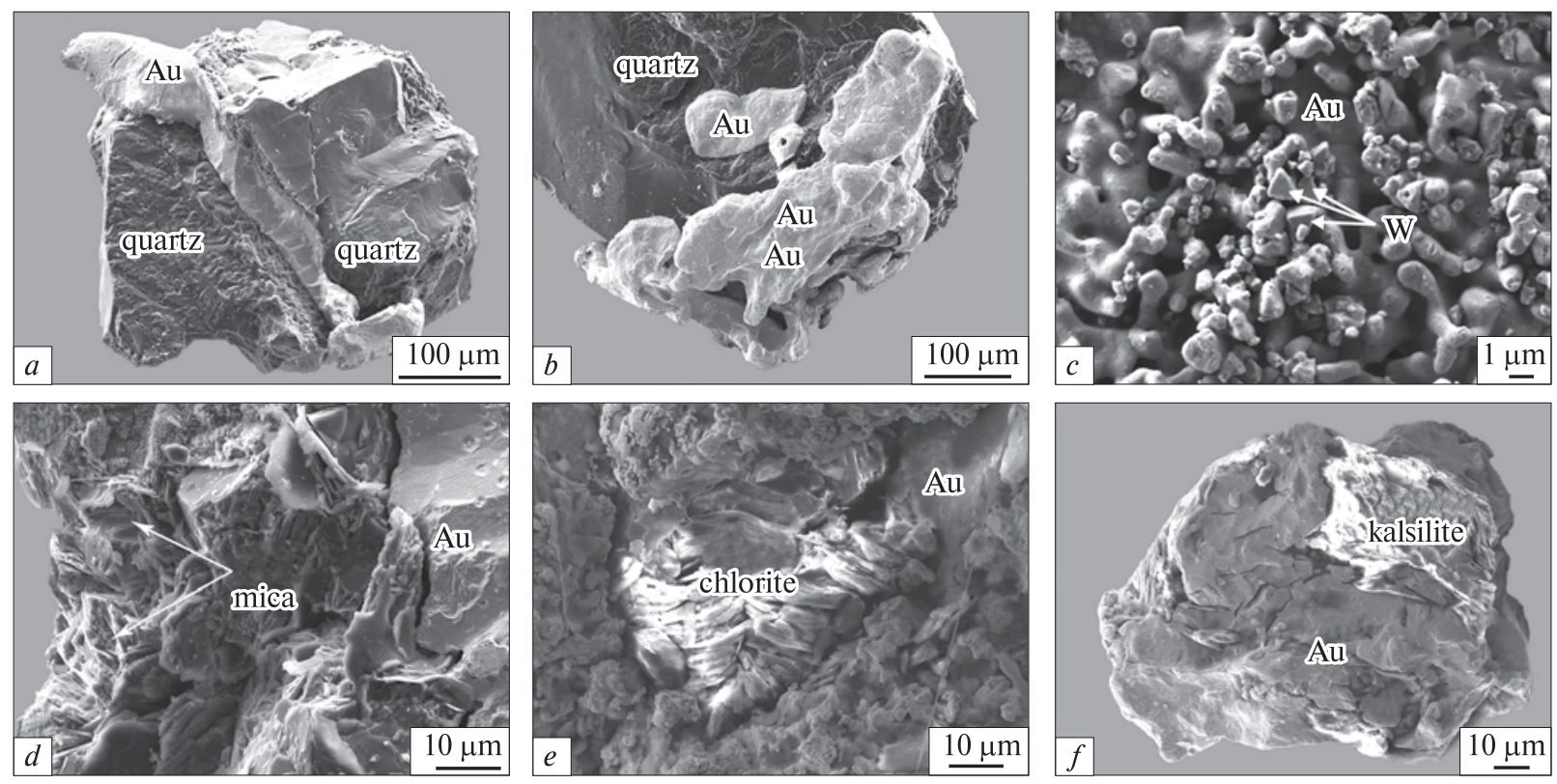

Fig. 6. Intergrowths of quartz $(a, b)$, micro-polyhedrons of native tungsten $(c)$, mica $(d)$, chlorite $(e)$, and kalsilite $(f)$ with native gold under the SEM, SEI mode 

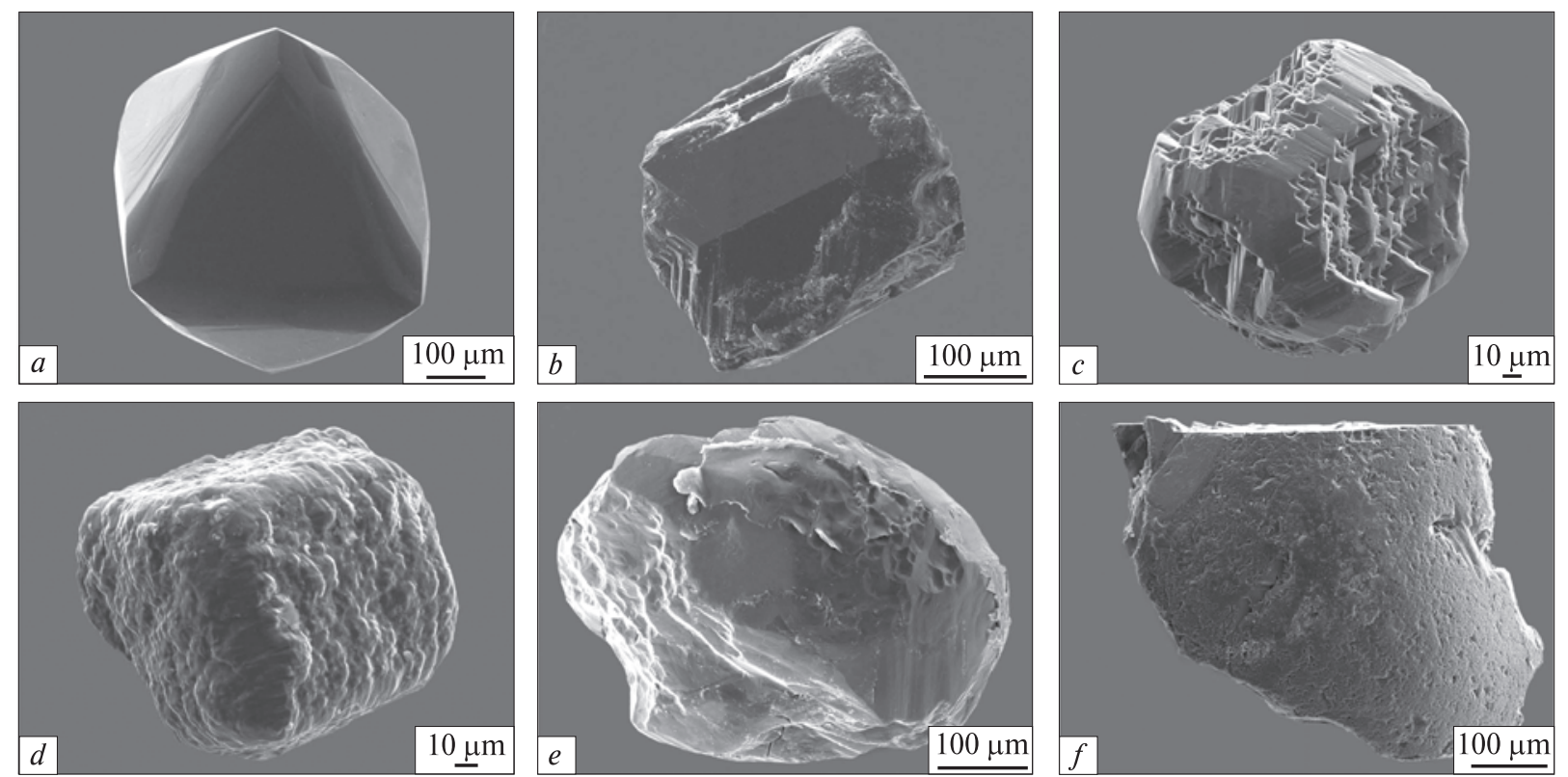

Fig. 7. Diamond crystals from the Bilokorovychi conglomerates under the SEM, SEI mode: $a-$ octahedron, $b-$ twin of octahedrons after (111), $c$ - cube with $\{111\}$ and $\{110\}$ forms, $d-$ cube, $e-$ rhombic dodecahedron with $\{100\}$ form, $f$ - rounded crystal
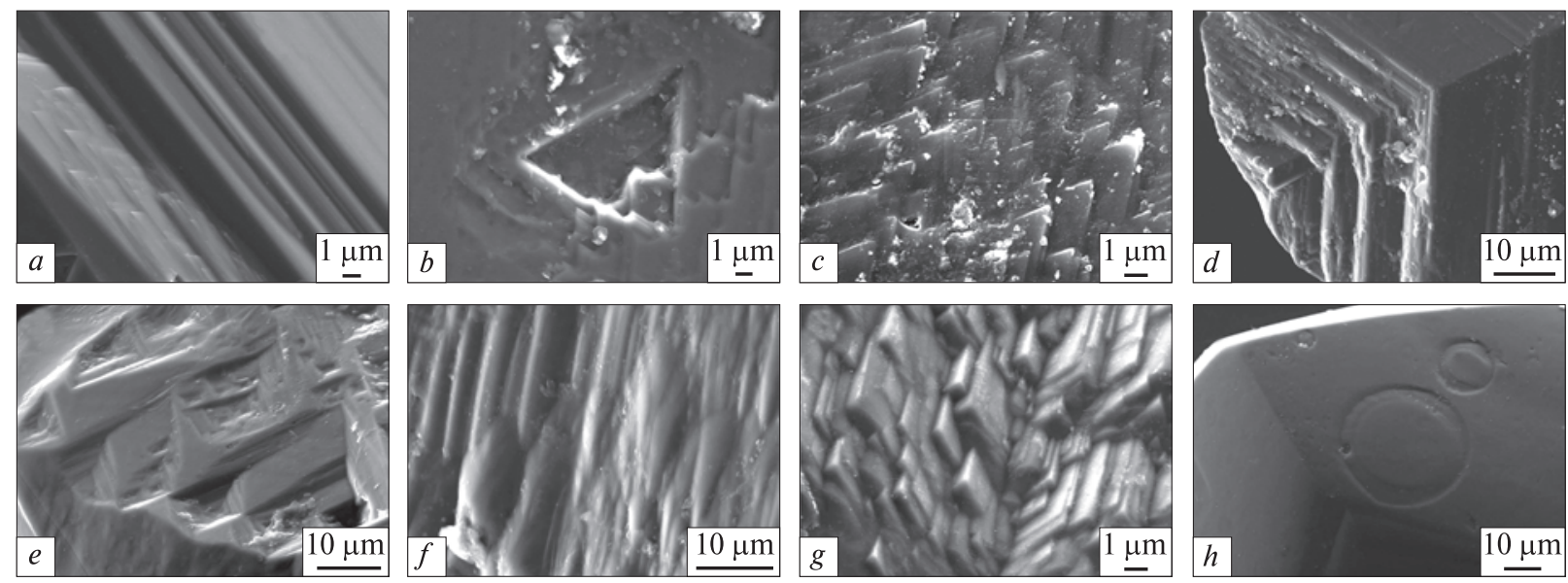

Fig. 8. Surface forms of the diamond crystals under the SEM, SEI mode: $a$ - parallel striation on the octahedron face; $b$ - inverse parallel triangular pits on the octahedron face; $c$ - positive triangular figures of polycentric growth on the octahedron face; $d$ - twin striation on contact of two octahedrons; $e-$ rectangular pits on the cube face; $f-$ drop-like figures on the rhombic dodecahedron rounded face; $g$ - tile-like figures on the rhombic dodecahedron rounded face; $h-$ disk-like figures on the rhombic dodecahedron rounded face

Many of crystals are damaged or broken, heavily rounded crystals are also present. Topography of the Bilokorovychi diamond crystals which is typical for kimberlitic and lamproitic diamonds is shown in Fig. 8. Diamonds from the Bilokorovychi basin have some indicators of their "antiquity" which are common for Precambrian placer diamonds from various regions around the world. These indicators are a very contrasting size distribution of diamonds, a presence of both green and brown pigmentation, a large amount of dodecahedron and cubic crystals and a very intensive mechanical deterioration of crystal surface.

Infrared spectroscopy of diamond crystals. We have applied the infrared spectroscopy for investigation of fifteen diamond crystals. Ten of them belong to the physical type Ia; five diamonds which are mainly microcrystals, belong to the low nitrogen type IIa [31, 36]. The Ia type is represented by crystals that belong to two subtypes: IaA ( 4 crystals), and IaAB ( 6 crystals). Crystals of the IaA subtype contain only A nitrogen centers. Crystals of the ISSN 2519-2396. Mineral. Journ. (Ukraine). 2018. 40, No 3 


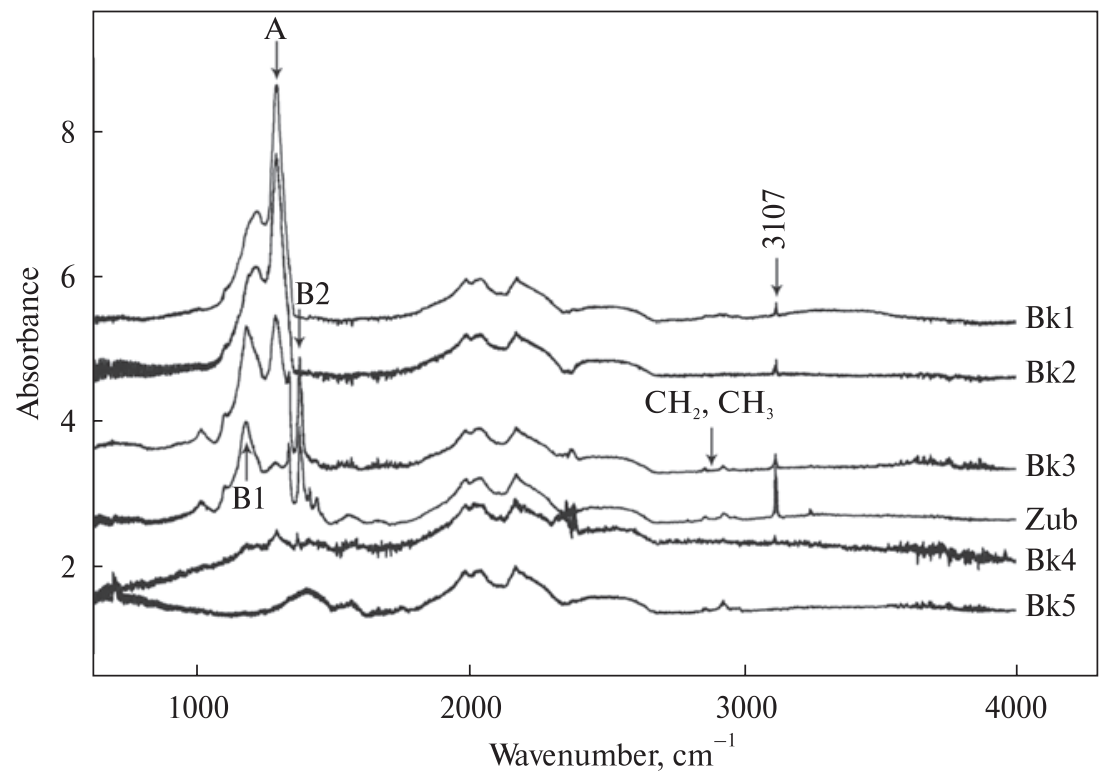

Fig. 9. FTIR spectra of the Bilokorovychi diamonds. Sample numbers correspond to the numbers in Table

IaAB subtype contain nitrogen centers $\mathrm{A}, \mathrm{B} 1$, and many of them have also B2 centers (so-called platelets, i. e. few-atoms-thick linear defects which develop by the accumulation of the interstitial carbon during B1 defects formation [26]). In terms of the degree of nitrogen aggregation crystals of the IaAB subtype are intermediate between subtypes $\mathrm{IaA}$ and IaB. Figure 9 displays a typical infrared spectra of the Bilokorovychi diamonds which were obtained using the Fourier spectrometer Bruker IFS-66. Nitrogen concentrations were measured in five diamonds (Table). The concentration of the aggregated nitrogen (A centers) in the IaAB subtype of the Bilokorovychi diamonds varies from 34 to $332 \mathrm{ppm}$ with the average of $174 \mathrm{ppm}$. These diamonds also contain from 24 to $182 \mathrm{ppm}(77 \mathrm{ppm}$ in the average) of the aggregated nitrogen that belongs to $\mathrm{B} 1$ centers. The total nitrogen concentration $\left(\mathrm{N}_{\mathrm{A}}+\mathrm{N}_{\mathrm{B} 1}\right)$ in these crystals varies from 60 to
$356 \mathrm{ppm}$, and the average concentration is $251 \mathrm{ppm}$ which is close to the average nitrogen concentration in kimberlitic and lamproitic diamonds. The degree of nitrogen aggregation $\left(\% \mathrm{~B}=\mathrm{N}_{\mathrm{B} 1} /\left(\mathrm{N}_{\mathrm{A}}+\mathrm{N}_{\mathrm{B} 1}\right)\right.$ ) varies from 7 to $54 \%$, with the average around $35 \%$. Four crystals of this subtype have a B2 center, with two of them having a rather high abundance of this center $\left(1.0\right.$ and $\left.2.1 \mathrm{~mm}^{-1}\right)$. There is a notable rise in the amount of the $\mathrm{B} 2$ center along with the $\mathrm{B} 1$ center increase. The main non-nitrogen centers are $>\mathrm{CH}=\mathrm{CH}_{2}$ and $\mathrm{CH}_{2}$ and $\mathrm{CH}_{3}$. Most of the spectra have carbonate absorption bands (1400$1480 \mathrm{~cm}^{-1}$ ), and weak carbonate bands 850$890 \mathrm{~cm}^{-1}$ and $680-710 \mathrm{~cm}^{-1}$. The three-dimensional investigations of some of the diamond crystals have revealed differences in the spatial distribution of A, B1 and B2 centers, and of hydrogen centers with bands in the range 2800$3000 \mathrm{~cm}^{-1}\left(\mathrm{CH}_{2}\right.$ and $\mathrm{CH}_{3}$ bonds $)$ and band

FTIR analyses of nitrogen concentration and its aggregation $(\% \mathrm{~B})$ in the Bilokorovychi diamonds

\begin{tabular}{|c|c|c|c|c|c|}
\hline \multirow{2}{*}{ Age of the sediments } & \multirow{2}{*}{ Habit, sample \# } & Center $\mathrm{A}-\mathrm{N}_{\mathrm{A}}$ & Center B1 $-\mathrm{N}_{\mathrm{B} 1}$ & $\left(\mathrm{~N}_{\mathrm{A}}+\mathrm{N}_{\mathrm{B} 1}\right)$ & \multirow{2}{*}{$\% \mathrm{~B}=\mathrm{N}_{\mathrm{B} 1} /\left(\mathrm{N}_{\mathrm{A}}+\mathrm{N}_{\mathrm{B} 1}\right)$} \\
\hline & & \multicolumn{3}{|c|}{ ppm } & \\
\hline \multirow[t]{4}{*}{ Palaeoproterozoic } & Fragment, Bk1 & 332 & 24 & 356 & 7 \\
\hline & Fragment, Bk2 & 296 & 0 & 296 & 0 \\
\hline & Octahedron, Bk3 & 156 & 182 & 338 & 54 \\
\hline & Octahedron, Bk4 & 34 & 26 & 60 & 43 \\
\hline Quaternary & Octahedron, Zub & 18 & 176 & 194 & 91 \\
\hline \multirow{2}{*}{\multicolumn{2}{|c|}{$\begin{array}{l}\text { Range } \\
\text { Average value }\end{array}$}} & $18-332$ & $0-182$ & $60-356$ & $0-91$ \\
\hline & & 167 & 82 & 249 & 38 \\
\hline
\end{tabular}



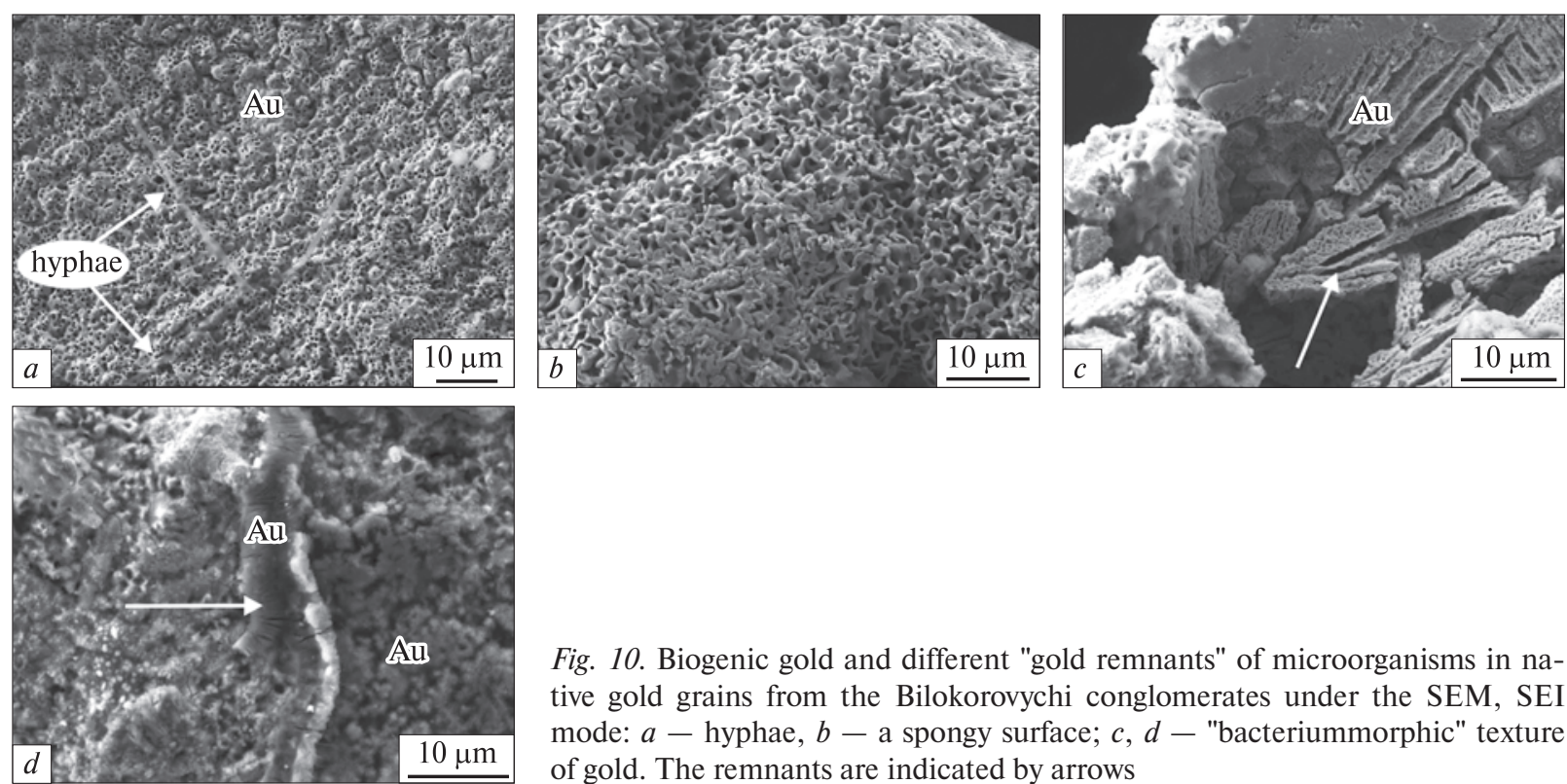

Fig. 10. Biogenic gold and different "gold remnants" of microorganisms in native gold grains from the Bilokorovychi conglomerates under the SEM, SEI mode: $a-$ hyphae, $b-$ a spongy surface; $c, d-$ "bacteriummorphic" texture of gold. The remnants are indicated by arrows

$3107 \mathrm{~cm}^{-1}\left(>\mathrm{CH}=\mathrm{CH}_{2}\right.$ bonds). Some of the crystals have a correlation between the abundance of A centers and intensity of the $3107 \mathrm{~cm}^{-1}$ band.

Discussion. The genesis of native gold. A wide spectrum of morphological types of native gold in the Bilokorovychi conglomerates and a large variability in its chemical composition suggests its complex origin and a possibly of petrological variation in its primary sources. We distinguish detrital and authigenic (including secondary) types of native gold. If we accept that gold was introduced to the conglomerates and was not formed in situ, i.e. that detrital gold (of primary hydrothermal origin) dominates, then the following model may be proposed. The bedrock sources of $\mathrm{Cu}$-rich native gold may include both silicic rocks and mafic-ultramafic igneous rocks. The pure native gold most probably originates from granitic sources, whereas Ag-rich gold may be derived from volcanic rocks. However, a problem with postulating a detrital origin of gold in the Bilokorovychi conglomerates is that most gold crystals do not exhibit sufficient mechanical deterioration or rounding. Most of the gold grains do not have any signs of deterioration and often occur in intergrowth with quartz, mica, and chlorite. This mineral association is an important indicator that the gold formed directly in the conglomerate and was not detrital in origin. It is important to note that many of the native gold grains from the Bilokorovychi conglomerate have indications of the later gold overgrowth that include crystallization of the secondary gold and of the biogenic gold. The secondary gold is represented by microcrystalline autoepitaxic overgrowths of native gold that occur as spongeous gold and micropolyhedrons of gold (Fig. 4). The biogenic gold includes typical forms of the porous gold and characteristic traces of the microorganisms activity (Fig. 10). The pseudomorphous replacement of bacteria and fungi by gold in nature and in experiments has been repeatedly described $[12,22$, 34]. The ability of microorganisms to extract and accumulate gold from the environment has been even considered as a possible mechanism of formation of low-temperature sedimentary gold deposits.

Hence, two main stages of gold formation in the Bilokorovychi conglomerates may be considered. During the first stage, the main amount of gold crystallized in situ, and the range in local conditions of crystallization had influenced variability of gold morphology and chemistry. The second stage included autoepitaxic deposition of secondary gold that was often enriched in $\mathrm{Cu}$. Under certain conditions, the authigenic formation of native gold was possible during diagenesis of the Bilokorovychi sediments through recrystallization of the detrital fine-dispersed gold. However, it is most likely that the main part of gold mineralization was formed during the regional metamorphism of the Bilokorovychi sediments. This assumption is supported by the presence of gold intergrowths with matrix minerals and by the predominant anhedral shape of the gold crystals. In such case, the mineralization may be classified as metamorphic-hydrothermal.

What was a source of the visible and fine-dispersed gold in the Bilokorovychi sediments? The 
basement crystalline rocks, and first of all silicified and pyrite-rich gneisses and crystalline schists of the Teteriv Series which are known to be goldenriched were considered as a possible source of gold [30]. The underlying rocks of the Teteriv Series in the southern part of the Bilokorovychi basin contain up to $2 \mathrm{ppm} \mathrm{Au}$. However, there are no published details on the morphology and chemistry of this gold. The common impurity in native gold hosted by gneisses is $\mathrm{Cu}$, and in native gold hosted by schists is $\mathrm{Zn}$. Gold occurences in association with sulfides of $\mathrm{As}, \mathrm{Ni}, \mathrm{Co}, \mathrm{Zn}$, and $\mathrm{Cu}$ are rare.

Gold mineralization of various mineralogicalgeochemical types is known in the neighboring areas. These include Stryivsky, Kyiansky and Ivanivsky occurrences of the gold-arsenite type in the Palaeoproterozoic metamorphic rocks of the Novohrad-Volynsky area, Mezhyrychi, Bilka and Potashnya occurrences of the gold-silver-quartz type in the Palaeoproterozoic metamorphic rocks of the Kocheriv tectonic zone, and Perga and Hlushkovychi occurrences of the gold-sulphide type in Perga granites [28]. Each of these types of gold mineralization has a distinct assemblage of indicative minerals: löllingite and arsenopyrite for the gold-arsenite type; quartz, tellurides, sulfoselenide, and sulfides for the gold-silver-quartz type; and pyrite, chalcopyrite, and sphalerite for the goldsulfide type. These occurrences were formed at 2100-1800 Ma [28].

Native gold from occurrences in the NovohradVolynsky area, by their chemistry, resembles gold from the Bilokorovychi basin. This gold is mainly anhedral and occurs as elongated, spherical, droplike, and equant grains. The purity of gold is up to 84-96\% [28]. According to the electron microprobe analysis, this gold contains such impurities as $\mathrm{Cu}, \mathrm{Bi}, \mathrm{Sb}, \mathrm{Fe}, \mathrm{Ag}, \mathrm{As}, \mathrm{S}$. All analyzed gold crystals (88-95\% Au, 3-10\% Ag) had $\mathrm{Cu}$ impurity. For instance, the Stryivsky occurrence contains $0.1-3.3 \% \mathrm{Cu}$, and some occurrences contain up to $20 \% \mathrm{Cu}$ [28].

Hence, taking into account the morphology and chemical composition of native gold from many occurrences in the North-Western region of the Ukrainian Shield, it is considered that the most probable source of the detrital gold supply was located to the southwest from the Bilokorovychi basin (present-day coordinates). The main argument for such interpretation is the observed geochemical association of gold and copper. It is hypothesized that all required material, including the detrital native gold (mainly in the fine-dispersed form) and the whole assemblage of associated chemical elements ( $\mathrm{Au}, \mathrm{Ag}, \mathrm{Cu}, \mathrm{W}$ etc.) was introduced during the weathering and denudation of crystalline rocks. This material was brought by a river system to the shore of the Precambrian Bilokorovychi basin, and crystallization of the main amount of gold, as well as further ingrowth of native gold and formation of the secondary gold, took place during conglomerate formation.

The genesis of diamond. Morphological types and surface forms of the studied crystals are typical for mantle-derived diamonds from kimberlites and lamproites. A first insight into the environment of crystallization of the Bilokorovychi diamonds may be obtained from carbon isotope studies. Two diamond crystals yielded the following $\delta^{13} \mathrm{C}$ values: -3.44 and -4.52 for the first crystal, and -27.33 for the second crystal [9]. "Heavy" carbon values for the first crystal fall into the range of $\delta^{13} \mathrm{C}$ values for diamonds of peridotite association, whereas both "heavy" and "light" values for both diamonds fall into the range of $\delta^{13} \mathrm{C}$ values that are common for diamonds of eclogite association from kimberlite and lamproite. In other words, according to their carbon isotope composition diamonds from the Bilokorovychi conglomerates can be attributed to kimberlite and lamproite diamonds that belong to the peridotite and eclogite associations.

According to the physical classification, the Bilokorovychi diamonds can be described as transitional from subtype IaA to subtype IaAB, with A-type defects being statistically dominant. The setting and amount of nitrogen and other revealed centers in the Bilokorovychi diamonds correspond to diamonds from kimberlite and lamproite. The concentration and the degree of nitrogen aggregation can be used to approximate the mantle residence temperature of the Bilokorovychi diamonds, assuming a mantle residence time of $2 \mathrm{Ga}$. It must be noted that the estimated temperature is relatively insensitive to the estimated residence time, as the relatively large variation $(1 \mathrm{Ga})$ in the mantle residence time will result in only a minor change $\left(15{ }^{\circ} \mathrm{C}\right)$ in the temperature estimate [10]. According to the nitrogen thermometry [23], the average temperature of diamonds with a residence time of $3 \mathrm{Ga}$ and a variable parent lithology (harzburgite, lherzolite, eclogite) is $1141-1174 \pm 50^{\circ} \mathrm{C}$. The calculated for the Bilokorovychi diamonds temperatures range from $<1050$ to $1185^{\circ} \mathrm{C}$ (Fig. 11). For instance, diamond $\mathrm{Bk} 1$ is close to the subtype $\mathrm{IaAB}$ and has an average nitrogen concentration of 356 ppm, a low B1 centers concentration, and no 


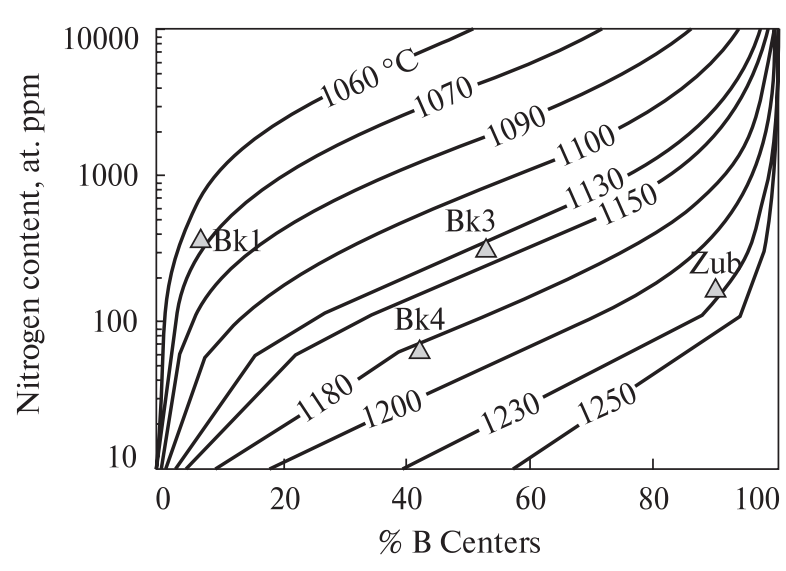

Fig. 11. Estimates of the Bilokorovychi diamonds crystallization temperature. Isotherms curves correspond to a mantle residence time of 2 Ga (after Taylor et al., 1990 [24]). Sample numbers correspond to the numbers in Table

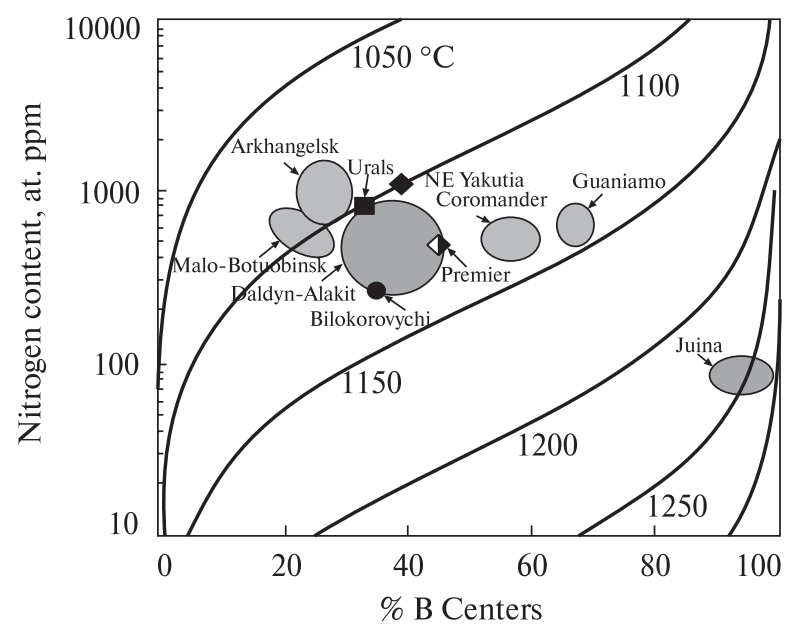

Fig. 12. The plot of the Bilokorovychi diamonds on the "nitrogen diagram" (after Kaminsky \& Khachatryan, 2001 [8]) in comparison with diamonds from various areas worldwide. Isotherm curves correspond to the mantle residence time of 3 Ga (after Taylor \& Milledge, 1995 [25])

B2 centers. The calculated average temperature of the nitrogen aggregation for this diamond is $<1070{ }^{\circ} \mathrm{C}$. Such temperature is typical for diamonds that have spent a long time under the conditions of the cold lithospheric geotherm $\left(<40 \mathrm{~mW} / \mathrm{m}^{2}\right)$. Diamond Bk2 belongs to the IaA subtype with a moderate average nitrogen concentration (296 ppm). An absence of the aggregated nitrogen in a form of $\mathrm{B} 1$ centers indicates that this diamond has resided at lower mantle temperature conditions $\left(<1050-1060{ }^{\circ} \mathrm{C}\right.$, possibly at shallower depths), or that it has spent less time in the mantle compared to diamond Bk1. Diamond Bk3 belongs to the subtype $\mathrm{IaAB}$ with an average nitrogen concentration of $338 \mathrm{ppm}$ and a high amount of B1 and $\mathrm{B} 2$ centers. The average temperature of nitrogen aggregation in this diamond is rather high $1135{ }^{\circ} \mathrm{C}$. Such diamonds either originated from larger depths or belong to an older generation. Diamond $\mathrm{Bk} 4$ is close to the IaAB subtype and has very low nitrogen concentration $(60 \mathrm{ppm})$, significant nitrogen aggregation in the $\mathrm{B} 1$ centers and a small amount of $\mathrm{B} 2$ centers. The aggregation temperature in this crystal is as high as $1185^{\circ} \mathrm{C}$. Such temperatures are atypical for Archaean diamonds. Finally, diamond Zub belongs to the IaAB subtype with low nitrogen abundance (194 ppm) and a high concentration of B1 and B2 centers. The calculated temperature of nitrogen segregation is about $1225{ }^{\circ} \mathrm{C}$, which is also too high for Archaean diamonds.

According to the average concentrations of the aggregated nitrogen and the number of B centers, the Bilokorovychi diamonds plot on the Taylor et al. (1990) [24] diagram within the field of the Yakutia province kimberlite diamonds (Fig. 12). These diamonds from conglomerates and especially diamond from the Quaternary sediments (i.e. diamond Zub) are derived from a high-temperature lithospheric source which is typical for Proterozoic diamonds. Their crystallization may happen in the Proterozoic mantle as a result of the orogenic processes at the margin of the Archaean craton which caused thickening of the lithosphere and tectonothermal overworking of the primary Archean lithosphere. In contrast, a low degree of nitrogen aggregation (subtype IaA) in some of the diamonds indicates that these diamonds have grown and resided in a lithospheric mantle that had a low geothermal gradient. That could be thick stable cold lithosphere located beneath the old Archaean cratons.

The average concentration of nitrogen in the studied diamonds does not allow identification of their mantle lithology, although the value is quite close to the average concentration of nitrogen in diamonds of the eclogitic association. It has been proved statistically that average nitrogen concentration in diamonds of the eclogite association is several times higher than that in diamonds of the peridotite association [14, 23]. This observation is especially well-defined for kimberlitic diamonds from the Kaapvaal craton in South Africa which have average nitrogen concentrations of 519 and $75 \mathrm{ppm}$ for "eclogitic" and "peridotitic" diamonds respectively [21].

Diamonds and plate tectonics. In the recent 2030 years, the subduction model of a diamond formation in the mantle [14, 23] has been gaining ISSN 2519-2396. Mineral. Journ. (Ukraine). 2018. 40, No 3 
more and more support. There is increasing evidence that the mineralogy of mantle diamonds is controlled by the lithological and geochemical compositions of the subducted rocks. This is especially true for diamonds of the eclogitic assemblage $[14,23]$. This argumentation is based on the crystal morphology of diamonds, their carbon isotope systematics and amount and state of nitrogen admixture. In contrast to diamonds of the peridotitic assemblage, eclogitic diamonds have a wide range of crystal morphological types, large variations of carbon isotope composition (from -41.3 to $+2.7 \delta^{13} \mathrm{C}$ ) and a much higher average concentration of nitrogen.

The Bilokorovychi diamonds are quite variable and most probably belong to the eclogite type. Taking into account the mineralogical studies of these diamonds, and results of the geochronological and geodynamical investigations of the area, we suggest a hypothesis of their subduction-related origin. The North-Western region of the Ukrainian Shield that hosts the Bilokorovychi basin was formed in the Palaeoproterozoic. It developed initially as an accretionary prism at the margin of the Archaean Dniester-Bug Domain and was consequently metamorphosed and intruded by numerous granite intrusions at 2150-2050 Ma [16]. This process was induced by continuous subduction of the oceanic lithosphere in a southward direction in modern coordinates [4]. At 2000-1980 Ma the Osnitsk-Mikashevychi Igneous Belt developed on the northern border of the newly-formed continental margin [15]. The process of gradual accretion of the newly-formed continental crust continued until c. $1800 \mathrm{Ma}$, when the collision of the Sarmatian and Fennoscandian segments of the East European platform occurred [2, 5, 35]. Hence, subduction-related crust-forming processes were active for some 350 M.y., from 2150 to 1800 Ma. During this time span, a sufficient portion of the juvenile continental crust was formed.

At c. 1815-1740 Ma Sarmatia has experienced a large-scale magmatic event that was caused either by rotation and accompanied extension after the collision of Sarmatia and Fennoscandia [3, 20], or by emplacement of a mantle plume [17, 19]. The latter model is supported by a wide range of mantlederived melts that originated at different levels in the mantle. Kimberlites known in the central part of the Ukrainian Shield [41] belong to this association of the mantle-derived melts. All these data indicate that the geological situation, i.e. long-lasting subduction that was followed by the emplacement of kimberlitic melts, was favorable for the formation of sedimentary deposits bearing diamonds of eclogitic paragenesis. No kimberlite bodies are known in the vicinity of the Bilokorovychi basin. However, several bodies of the Palaeorpoterozoic alkaline ultramafic rocks are known in that area $[40,42,43]$ indicating the possibility of a presence of kimberlites and lamproites.

Finally, we should note (Mariusz Paszkowski, personal comm., 2017) that the Bilokorovychi basin has a lot features in common with the Roraima Supergroup in South America that is a major source of detrital diamonds [13]. The Roraima Supergroup was accumulated in two separate foreland basins while their sedimentary fill was derived from the Trans-Amazon and the TapajósParima orogenic belts. Zircons from the tuffs within the Supergroup yielded a Paleoproterozoic age of $1873 \pm 3 \mathrm{Ma}$, while the minimum age was defined as $1782 \pm 3$ Ma by U-Pb baddeleyite and zircon ages from two mafic sills that represent the Avanavero LIP magmatism which is probably equivalent to the mentioned above large-scale magmatic event in the Ukrainian Shield. The thickness of the Roraima Supergroup, in which sandy continental deposits predominate, range from 200 to $\sim 3000 \mathrm{~m}$. So, in terms of the tectonic setting, age, thickness and lithological composition the Roraima Supergroup in South America is very similar to the Topilnya Series that fills the Bilokorovychi basin. According to some of the paleotectonic reconstructions [7, 11], in the Proterozoic the western margin of Baltica (the East European platform) was located in front of Amazonia. Accordingly, the Ukrainian Shield was neighbored by the Guiana shield, i.e. coeval Topilnya Series and Roraima Supergroup might represent parts of the same (or similar) regional basin.

Conclusions. According to its morphology, chemistry, and mineral assemblages, native gold from the Bilokorovychi conglomerates can be subdivided into two types: detrital (rare type), and authigenic (prevailing type), including biogenic and secondary gold. Detrital gold includes rare rounded crystals. The primary authigenic gold is represented by anhedral massive crystals, whereas the secondary authigenic gold includes microovergrowths on the primary gold. Overgrown crystals vary from crystallographically deformed to ideal octahedrons and their intergrowths, including skeletal octahedrons, twins and fivelings of octahedrons. The porous spherical segregations and pseudomorphic grains after various microorganisms belong to the bioge- 
nic gold. Chemically gold is variable and belongs to pure, silvery with a large impurity of $\mathrm{Ag}$ and $\mathrm{Cu}$, cupriferous, etc. Pure gold prevails.

Based on infrared spectroscopy data, the Bilokorovychi diamonds belong to medium-low nitrogen varieties with variable degrees of nitrogen center aggregation. It is interpreted that these diamonds have resided in the mantle at a range of temperatures that was characteristic for the Archaean-Palaeoproterozoic age. Results of morphological, spectroscopic and isotope investigations can indirectly indicate their source. The most probable parent rock is eclogite, whereas harzburgite and lherzolite are less probable. It should be also noted that Precambrian diamonds originate from various sources, including kimberlite, lamproite, lamprophyre, metakomatiite, phyllite etc., whereas the Phanerozoic diamonds come mainly from kimberlite and only a few of them are derived from lamproite. Taking all these data into account, we assume that primary sources for diamonds from the Bilokorovychi conglomerates were kimberlites, lamproites or other rocks whose age exceeded 1800 Ma. Their well-rounded shape may indicate prolonged transportation from the source to the site of accumulation.

A recent advance in the investigation of diamonds favors the subduction model of the origin of this mineral. Geological, geochemical and geochronological data regarding the North-Western region of the Ukrainian Shield that hosts the Bilokorovychi basin indicate that the whole area was formed between c. 2150 and 1980 Ma due to continuous subduction of the oceanic lithosphere and gradual accretion of the newly-formed continental crust to the margin of the Archaean core. A large-scale magmatic event that started at c. $1815 \mathrm{Ma}$ could be a suitable transporter of the mantle-derived material, including diamonds, to the surface.

Acknowledgements. We are grateful to Richard Ernst for checking and editing the manuscript, to Borys Vysotskyi for providing us samples, and to Mykhail Taran, Ivan Gurnenko, Oleksandra Pavlyuk and Oleksiy Vyshnevskyi for their valuable help in carrying out this research. We also thank to Felix Kaminsky and Bogustaw Baginski for the positive reviews.

\section{REFERENCES}

1. Amelin Yu.V., Heaman L.M., Verchogliad V.M., Skobelev V.M. Geochronological constraints on the emplacement history of an anorthosite-rapakivi granite suite: $\mathrm{U}-\mathrm{Pb}$ zircon and baddeleyite study of the Korosten complex, Ukraine // Contribs Mineral. and Petrol. - 1994. - 116. - P. 411-419. — doi: https://doi.org/10.1007/BF00310908

2. Bogdanova S.V., Bingen B., Gorbatschev R., Kheraskova T.N., Kozlov V.I., Puchkov V.N., Volozh Y.A. The East European Craton (Baltica) before and during the assembly of Rodinia // Precam. Res. - 2008. - 160. - P. 23 - 45. — doi: https:// doi.org/10.1016/j.precamres.2007.04.024

3. Bogdanova S.V., Gintov O.B., Kurlovich D., Lubnina N.V., Nilsson M., Orlyuk M.I., Pashkevich I.K., Shumlyanskyy L.V., Starostenko V.I. Late Palaeoproterozoic mafic dyking in the Ukrainian Shield (Volgo-Sarmatia) caused by rotations during the assembly of supercontinent Columbia // Lithos. - 2013. - 174. - P. 196-216. - doi: https://doi. org/10.1016/j.lithos.2012.11.002

4. Claesson S., Bogdanova S.V., Bibikova E.V., Gorbatschev R. Isotopic evidence for Palaeoproterozoic accretion in the basement of the East European Craton // Tectonophysics. - 2001. - 339. - P. 1-18. — doi: https://doi.org/10.1016/ S0040-1951(01)00031-2

5. Elming S-Å., Mikhailova N.P., Kravchenko S.N. The consolidation of the East European Craton: a palaeomagnetic analysis of Proterozoic rocks from the Ukrainian Shield and tectonic reconstruction versus Fennoscandia // Geoph. J. - 1998. - 20 (4). - P. 71-74.

6. Gorokhov I.M., Clauer N., Varshavskaya E.S., Kutyavin E.P., Drannik A.S. Rb-Sr ages of Precambrian sediments from the Ovruch mountain range, northwestern Ukraine (U.S.S.R.) // Precam. Res. - 1981. - 16. - P. 55-65. - doi: https://doi.org/10.1016/0301-9268(81)90005-X

7. Johansson A. Baltica, Amazonia and the SAMBA connection - 1000 million years of neighbourhood during the Proterozoic? // Precam. Res. - 2009. - 175. - P. 221-234. - doi: https://doi.org/10.1016/j.precamres.2009.09.011

8. Kaminsky F.V., Khachatryan G.K. Characteristics of nitrogen and other impurities in diamond as revealed by infrared absorption data // Canad. Mineral. - 2001. - 39. - P. 1733-1745. — doi: https://doi:10.2113/gscanmin.39.6.1733

9. Kvasnitsa V.N., Silaev V.I., Smoleva I.V. Carbon isotopic composition of diamonds in Ukraine and their probable polygenetic nature // Geochem. Inter. - 2016. - 54. - P. 948-963. - doi: https://doi.org/10.1134/ S0016702916090020

10. Leahy K., Taylor W.R. The influence of the Glennie domain deep structure on the diamonds in Saskatchewan kimberlites // Rus. Geol. Geoph. - 1997. - 38. - P. 481-491.

11. Li Z.X., Bogdanova S.V., Collins A.S., Davidson A., De Waele B., Ernst R.E., Fitzsimons I.C.W., Fuck R.A., Gladkochub D.P., Jacobs J., Karlstrom K.E., Lu S., Natapov L.M., Pease V., Pisarevsky S.A., Thrane K., Vernikovsky V. Assem- 
bly, configuration, and break-up history of Rodinia: a synthesis // Precam. Res. — 2008. - 160. - P. 179-210. - doi: https://doi.org/10.1016/j.precamres.2007.04.021

12. Reith F., Rogers S.L., McPhail D.C., Webb D. Biomineralization of Gold: Biofilms on Bacterioform Gold // Science. 2006. - 313. - P. 233-236. - doi: https://doi.org/10.1126/science.1125878

13. Santos J.O.S., Potter P.E., Reis N.J., Hartmann L.A., Fletcher I.R., McNaughton N.J. Age, source, and regional stratigraphy of the Roraima Supergroup and Roraima-like outliers in northern South America based on U-Pb geochronology // GSA Bulletin. - 2003. - 115 (3). - P. 331-348. - doi: https://doi.org/10.1130/0016-7606(2003)115< $<0331$ :ASARSO $>2.0 . \mathrm{CO} ; 2$

14. Shirey B.S., Cartigny P., Frost J.D., Keshav Sh., Nestola F., Nimis P., Pearson G.D., Sobolev N.V., Walter J.M. Diamonds and the geology of mantle carbon // Rev. Mineral. Geochem. - 2013. - 75. - P. 355-421. - doi: https://doi. org/10.2138/rmg.2013.75.12

15. Shumlyanskyy L. Geochemistry of the Osnitsk-Mikashevichy volcanoplutonic complex of the Ukrainian Shield // Geochem. Inter. - 2014. - 52. - P. 912-924. - doi: https://doi.org/10.1134/S0016702914110081

16. Shumlyanskyy L., Bekker A., Billström K., Claesson S., Romer R.L., Albekov A., Rudenko K. Geochronology and geodynamic setting of Rhyacian (2.25-2.03 Ga) orogenic zones in Sarmatia (SW Baltica) // Proc. of the 14th SGA Biennial Meeting, 20-23 Aug. 2017, Québec City, Canada. - 2017. - P. 253-256.

17. Shumlyanskyy L., Hawkesworth C., Billström K., Bogdanova S., Mitrokhin O., Romer R., Dhuime B., Claesson S., Ernst R., Whitehouse M., Bilan O. The origin of the Palaeoproterozoic AMCG complexes in the Ukrainian Shield: new U-Pb ages and Hf isotopes in zircon // Precam. Res. - 2017. - 292. - P. 216-239. - doi: https://doi.org/10.1016/j. precamres.2017.02.009

18. Shumlyanskyy L., Hawkesworth C., Dhuime B., Billström K., Claesson S., Storey C. ${ }^{207} \mathrm{~Pb} /{ }^{206} \mathrm{~Pb}$ ages and Hf isotope composition of zircons from sedimentary rocks of the Ukrainian Shield: crustal growth of the south-western part of East European craton from Archaean to Neoproterozoic // Precam. Res. - 2015. - 260. - P. 39-54. — doi: https://doi. org/10.1016/j.precamres.2015.01.007

19. Shumlyanskyy L., Mitrokhin O., Billström K., Ernst R., Vishnevska E., Tsymbal S., Cuney M., Soesoo A. The ca. 1.8 Ga mantle plume related magmatism of the central part of the Ukrainian Shield // Geologiska Föreningen Stockholm Förhandlingar. - 2016. - 138. - P. 86-101. — doi: https://doi.org/10.1080/11035897.2015.1067253

20. Shumlyanskyy L., Billström K., Hawkesworth C., Elming $S$-Å. U-Pb age and Hf isotope compositions of zircons from the north-western region of the Ukrainian Shield: mantle melting in response to post-collision extension // Terra Nova. 2012. - 24. - P. 373-379. - doi: https://doi.org/10.1111/j.1365-3121.2012.01075.x

21. Smart K.A., Tappe S., Stern R.A., Webb S.J., Ashwal L.D. Early Archaean tectonics and mantle redox recorded in Witwatersrand diamonds // Nature Geo. - 2016. - 9. - P. 255-259. - doi: https://doi.org/10.1038/ngeo2628

22. Southam G., Lengke M.F., Fairbrother L., Reith F. The biogeochemistry of gold // Elements. - 2009. - 5 (5). P. 303-307.

23. Stachel T., Harris J.W. The origin of cratonic diamonds - Constraints from mineral inclusions // Ore Geol. Rev. 2008. - 34. - P. 5-32. - doi: https://doi.org/10.1016/j.oregeorev.2007.05.002

24. Taylor W.R., Jagues A.L., Ridd M. Nitrogen-defect aggregation characteristics of some Australasian diamonds: Timetemperature constraints on the source regions of pipe and alluvial diamonds // Amer. Miner. - 1990. - 75. - P. $1290-1310$.

25. Taylor W.R., Milledge H.J. Nitrogen aggregation character, thermal history and stable isotope composition of some xenolith-derived diamonds from Roberts Victor and Finch // Sixth International Kimberlite Conference. Extended Abstracts. - Novosibirsk, 1995. - P. 620-622.

26. Woods G.S. Platelets and the infrared absorbance of Type Ia diamonds // Proc. Royal. Soc. - 1986. - A407. P. 219-238. - doi: https://doi.org/10.1098/rspa.1986.0094

27. Беспалько Н.А. Геологическое положение пород Белокоровичской структуры // Геол. журн. - 1986. - 46, № 3. - C. 25-33.

28. Бондаренко С.М., Сьомка В.О., Грінченко О.В. Ендогенне золото в докембрійських комплексах Волинського мегаблока (Український щит) // Зап. Укр. мінерал. т-ва. - 2015. - 12. - С. 119-131.

29. Букович И.П. Стратиграфия Вильчанской, Овручской и Белокоровичской впадин // Геол. журн. - 1986. - 46, № 2. - С. 102-110.

30. Вербицкий В.Н., Комаров А.Н. К вопросу о золотоносности Овручского палеорифта (северо-западная часть Украинского щита) // Геол. журн. - 1993. - № 5. - С. 48-52.

31. Ільченко К.О., Квасниия В.М., Таран М.М. Мікроалмази із кімберлітів і розсипні алмази України: їх особливості за даними інфрачервоної спектроскопії // Зап. Укр. мінерал. т-ва. - 2007. - 4. - С. 13-37.

32. Квасниця В.М., Павлюк О.В., Вишневський О.А., Квасниця І.В., Висоцький Б.Л., Гурненко І.В. Самородне золото із білокоровицьких протерозойських конгломератів Волині // Зап. Укр. мінерал. т-ва. - 2015. - 12. C. $103-116$.

33. Костенко М.М. Особливості магматизму Білокоровицької палеозападини (північна частина Українського щита) // Зб. наук. пр. УкрДГРІ. - 2011. - № 3. - С. 21-49.

34. Куимова Н.Г., Моисеенко В.Г. Биогенная минерализация золота в природе и эксперименте // Литосфера. 2006. - 3. - C. 83-95. 
35. Лубнина Н.В., Богданова С.В., Шумлянский Л.В. Восточно-Европейский кратон в палеопротерозое: новые палеомагнитные определения по магматическим комплексам Украинского щита // Геофизика. - 2009. 5. - C. 56-64.

36. Металиди С.В., Зарицкий А.И., Цымбал С.Н., Потебня М.Т., Квасница В.Н., Слыш Р.А., Язвинский В.И. Первая находка алмазов в конгломератах верхнего протерозоя на территории Восточно-Европейской платформы // Минерал. журн. - 1982. - 4, № 3. - С. 20-29.

37. Щербак Н.П., Артеменко Г.В., Лесная И.М., Пономаренко А.Н., Шумлянский Л.В. Геохронология раннего докембрия Украинского щита. Протерозой. - Киев : Наук. думка, 2008. - 240 с.

38. Щербак Н.П., Есипчук К.Е., Берзенин Б.З., Глевасский Е.Б., Дранник А.С., Пийяр Ю.К., Полуновский Р.М., Скаржинская Т.А., Соловицкий В.Н., Этингоф И.М., Билынская Я.П., Ганоцкий В.И., Гузенко Г.Ф., Киселев А.С., Клочков В.М., Решетняк В.В., Босая Н.И., Воронова С.Г., Пилипенко В.И. Стратиграфические разрезы докембрия Украинского щита. - Киев : Наук. думка, 1985. - 168 с.

39. Шумлянський Л.В., Мазур М.Д. Вік та речовинний склад йотунітів Білокоровицького дайкового поясу // Геолог України. - 2010. - № 1-2. - С. 70-78.

40. Цымбал С.Н., Гейко Ю.В., Кривдик С.Г., Баран А.Н., Цымбал Ю.С. Болярковская интрузия щелочно-ультраосновных пород (северо-запад Украинского щита) // Актуальные проблемы геологии Беларуси и смежных территорий : Тр. Междунар. науч. конф. (Минск, 8-9 дек. 2008 г.). - Минск, 2008. - С. 35-40.

41. Цымбал С.Н., Кривдик С.Г., Кирьянов Н.Н., Макивчук О.Ф. Вещественный состав кимберлитов Кировоградского геоблока (Украинский щит) // Минерал. журн. - 1999. - 21, № 2/3. - С. 22-38.

42. Цымбал С.Н., Щербаков И.Б., Кривдик С.Г., Лабузный В.Ф. Щелочно-ультраосновные породы Городницкой интрузии (Северо-Запад Украинского щита) // Минерал. журн. - 1997. - 19, № 3. - С. 61-80.

43. Цымбал С.Н., Шумлянский Л.В., Степанюк Л.М. Возраст щелочно-ультраосновных пород городницкого и гранитоидов шереметьевского комплексов северо-западной части Украинского щита // Зб. тез Міжнар. наук. конф. (до 90-чя акад. М.П. Щербака) "Геохронологія та геодинаміка раннього докембрію (3,6-1,6 млрд рр.) Евразійського континенту (Київ, 16-17 верес. 2014 р.) / ІГМР НАН України. - К. : Компринт, 2014. C. $121-122$.

Надійшла 25.01.2018

1. Amelin, Yu.V., Heaman, L.M., Verkhogliad, V.M. and Skobelev, V.M. (1994), Contribs Mineral. and Petrol., Vol. 116, pp. 411-419, doi: https://doi.org/10.1007/BF00310908

2. Bogdanova, S.V., Bingen, B., Gorbatschev, R., Kheraskova, T.N., Kozlov, V.I., Puchkov, V.N. and Volozh, Y.A. (2008), Precam. Res., Vol. 160, pp. 23-45, doi: https://doi.org/10.1016/j.precamres.2007.04.024

3. Bogdanova, S.V., Gintov, O.B., Kurlovich, D., Lubnina, N.V., Nilsson, M., Orlyuk, M.I., Pashkevich, I.K., Shumlyanskyy, L.V. and Starostenko, V.I. (2013), Lithos, Vol. 174, pp. 196-216, doi: https://doi.org/10.1016/j.lithos.2012.11.002

4. Claesson, S., Bogdanova, S.V., Bibikova, E.V. and Gorbatschev, R. (2001), Tectonophysics, Vol. 339, pp. 1-18, doi: https://doi.org/10.1016/S0040-1951(01)00031-2

5. Elming, S-Å., Mikhailova, N.P. and Kravchenko, S.N. (1998), Geoph. J., Vol. 20 (4), pp. 71-74.

6. Gorokhov, I.M., Clauer, N., Varshavskaya, E.S., Kutyavin, E.P. and Drannik, A.S. (1981), Precam. Res., Vol. 16, pp. 55-65, doi: https://doi.org/10.1016/0301-9268(81)90005-X

7. Johansson, A. (2009), Precam. Res., Vol. 175, pp. 221-234, doi: https://doi.org/10.1016/j.precamres.2009.09.011

8. Kaminsky, F.V. and Khachatryan, G.K. (2001), Canad. Miner., Vol. 39, pp. 1733-1745, doi: doi:10.2113/gscanmin. 39.6.1733

9. Kvasnytsya, V.M., Silaev, V.I. and Smoleva, I.V. (2016), Geochem. Inter., Vol. 54, pp. 948-963, doi: https://doi. org/10.1134/S0016702916090020

10. Leahy, K. and Taylor, W.R. (1997), Rus. Geol. Geoph., Vol. 38, pp. 481-491.

11. Li, Z.X., Bogdanova, S.V., Collins, A.S., Davidson, A., De Waele B., Ernst, R.E., Fitzsimons, I.C.W., Fuck, R.A., Gladkochub, D.P., Jacobs, J., Karlstrom, K.E., Lu, S., Natapov, L.M., Pease, V., Pisarevsky, S.A., Thrane, K. and Vernikovsky, V. (2008), Precam. Res., Vol. 160, pp. 179-210, doi: https://doi.org/10.1016/j.precamres.2007.04.021

12. Reith, F., Rogers, S.L., McPhail, D.C. and Webb, D. (2006), Science, Vol. 313, pp. 233-236, doi: 10.1126/ science. 1125878

13. Santos, J.O.S., Potter, P.E., Reis, N.J., Hartmann, L.A., Fletcher, I.R. and McNaughton, N.J. (2003), GSA Bulletin, Vol. 115 (3), pp. 331-348, doi: https://doi.org/10.1130/0016-7606(2003)115<0331:ASARSO >2.0.CO;2

14. Shirey, B.S., Cartigny, P., Frost, J.D., Keshav, Sh., Nestola, F., Nimis, P., Pearson, G.D., Sobolev, N.V. and Walter, J.M. (2013), Rev. Mineral. Geochem., Vol. 75, pp. 355-421, doi: https://doi.org/10.2138/rmg.2013.75.12

15. Shumlyanskyy, L. (2014), Geochem. Inter., Vol. 52, pp. 912-924, doi: https://doi.org/10.1134/S0016702914110081

16. Shumlyanskyy, L., Bekker, A., Billström, K., Claesson, S., Romer, R.L., Albekov, A. and Rudenko, K. (2017), Proc. of the 14th SGA Biennial Meeting, 20-23 Aug. 2017, Québec City, CA, pp. 253-256.

17. Shumlyanskyy, L., Hawkesworth, C., Billström, K., Bogdanova, S., Mitrokhin, O., Romer, R., Dhuime, B., Claesson, S., Ernst, R., Whitehouse, M. and Bilan, O. (2017), Precam. Res., Vol. 292, pp. 216-239, doi: https://doi.org/10.1016/j. precamres.2017.02.009

18. Shumlyanskyy, L., Hawkesworth, C., Dhuime, B., Billström, K., Claesson, S. and Storey, C. (2015), Precam. Res., Vol. 260, pp. 39-54, doi: https://doi.org/10.1016/j.precamres.2015.01.007 
19. Shumlyanskyy, L., Mitrokhin, O., Billström, K., Ernst, R., Vishnevska, E., Tsymbal, S., Cuney, M. and Soesoo, A. (2016), Geologiska Föreningen Stockholm Förhandlingar, Vol. 138, pp. 86-101, doi: https://doi.org/10.1080/11035897. 2015.1067253

20. Shumlyanskyy, L., Billström, K., Hawkesworth, C. and Elming, S.-Å. (2012), Terra Nova, Vol. 24, pp. 373-379, doi: 10.1111/j.1365-3121.2012.01075.X

21. Smart, K.A., Tappe, S., Stern, R.A., Webb, S.J. and Ashwal, L.D. (2016), Nature Geo, Vol. 9, pp. 255-259, doi: https:// doi.org/10.1038/ngeo2628

22. Southam, G., Lengke, M.F., Fairbrother, L. and Reith, F. (2009), Elements, Vol. 5, pp. 303-307.

23. Stachel, T. and Harris, J.W. (2008), Ore Geol. Rev., Vol. 34, pp. 5-32, doi: https://doi.org/10.1016/j. oregeorev.2007.05.002

24. Taylor, W.R., Jagues, A.L. and Ridd, M. (1990), Amer. Miner., Vol. 75, pp. 1290-1310.

25. Taylor, W.R. and Milledge, H.J. (1995), Sixth Int. Kimberlite Conf., Extended Abstracts, Novosibirsk, RU, pp. $620-622$.

26. Woods, G.S. (1986), Proc. Royal. Soc., A407, pp. 219-238, doi: https://doi.org/10.1098/rspa.1986.0094

27. Bespalko, N.A. (1986), Geol. J., Vol. 46, No. 3, Kyiv, UA, pp. 25-33.

28. Bondarenko, S.M., Syomka, V.O. and Grinchenko, O.V. (2015), Proc. Ukrainian Mineral. Society, Vol. 12, Kyiv, UA, pp. 119-131.

29. Bukovych, I.P. (1986), Geol. J., Vol. 46, No. 2, Kyiv, UA, pp. 102-110.

30. Verbitsky, V.N. and Komarov, A.N. (1993), Geol. J., No. 5, Kyiv, UA, pp. 48-52.

31. Ilchenko, K.O., Kvasnytsya, V.M. and Taran, M.M. (2007), Proc. Ukrainian Mineral. Society, Vol. 4, Kyiv, UA, pp. 13-37.

32. Kvasnytsya, V.M., Pavlyuk, O.V., Vishnevsky, O.A., Kvasnytsya, I.V., Vysotsky, B.L. and Gurnenko I.V. (2015), Proc. Ukrainian Mineral. Society, Vol. 12, Kyiv, UA, pp. 103-116.

33. Kostenko, M.M. (2011), Proc. Ukrainian State Geol. Res. Institute, No. 3, Kyiv, UA, pp. 21-49.

34. Kuimova, N.G., Moiseenko, V.G. (2006), Litosphera, Vol. 3, Moscow, RU, pp. 83-95.

35. Lubnina, N.V., Bogdanova, S.V. and Shumlyanskyy, L.V. (2009), Geofizika (Geoph.), Vol. 5, Moscow, RU, pp. 56-64.

36. Metalidi, S.V., Zaritsky, A.I., Tsymbal, S.N., Potebnya, M.T., Kvasnytsya, V.M., Slysh, R.A. and Yazvinsky, V.I. (1982), Mineral. Journ. (Ukraine), Vol. 4, No. 3, Kyiv, UA, pp. 20-29.

37. Shcherbak, N.P., Artemenko, G.V., Lesnaya, I.M., Ponomarenko, A.N. and Shumlyanskyy, L.V. (2008), Geochronology of the Early Precambrian of the Ukrainian Shield. Proterozoic, Nauk. dumka, Kyiv, UA, 240 p.

38. Shcherbak, N.P., Esipchuk, K.E., Berzenin, B.Z., Glevasskiy, E.B., Drannik, A.S., Piyar, Yu.K., Polunovskiy, R.M., Skarzhinskaya, T.A., Solovickiy, V.N., Etingof, I.M., Bilynskaya, Ya.P., Ganockiy, V.N., Gusenko, G.F., Kiselev, A.S., Klochkov, V.M., Reshetnyak, V.V., Bosaya, N.I., Voronova, S.G. and Pilipenko, V.I. (1985), The Precambrian stratigraphic sections of the Ukrainian Shield, Nauk. dumka, Kyiv, UA, 168 p.

39. Shumlyanskyy, L.V. and Mazur, M.D. (2010), Geolog Ukraine, No. 1-2, Kyiv, UA, pp. 70-78.

40. Tsymbal, S.M., Geyko, Yu.V., Kryvdik, S.G., Baran, A.N. and Tsymbal, Yu.S. (2008), Abstract volume of the Int. sci. conf., Minsk, 8-9 Decem. 2008, Minsk, Belorussia, pp. 35-40.

41. Tsymbal, S.N., Kryvdik, S.G., Kiryanov, N.N. and Makivchuk, O.F. (1999), Mineral. Journ. (Ukraine), Vol. 21, No. 2-3, Kyiv, UA, pp. 22-38.

42. Tsymbal, S.N., Shcherbakov, I.B., Kryvdik, S.G. and Labuznyi, V.F. (1997), Mineral. Journ. (Ukraine), Vol. 19, No. 3, Kyiv, UA, pp. 61-80.

43. Tsymbal, S.N., Shumlyanskyy, L.V. and Stepanyuk, L.M. (2014), Abstract volume of the Intern. sci. conf. dedicated to the 90-th anniversary of Academ. of the NAS of Ukraine M.P. Shcherbak, Kyiv, 16-17 Sept. 2014, Kyiv, UA, pp. 121-122.

Received 25.01.2018

\author{
В.М. Квасниия, Л.В. Шумлянський \\ Інститут геохімії, мінералогії та рудоутворення \\ ім. М.П. Семененка НАН України \\ 03142, м. Київ, Україна, пр-т Акад. Палладіна, 34 \\ E-mail:vmkvas@hotmail.com; lshumlyanskyy@yahoo.com \\ САМОРОДНЕ ЗОЛОТО І АЛМАЗИ ІЗ ПАЛЕОПРОТЕРОЗОЙСЬКИХ \\ ТЕРИГЕННИХ ПОРІД БІЛОКОРОВИЦЬКОЇ СТРУКТУРИ, \\ ПІВНІЧНО-ЗАХІДНИЙ РАЙОН УКРАЇНСЬКОГО ЩИТА
}

Білокоровицька структура розташована у Північно-Західному районі Українського щита. Її ширина складає від 2 до 6 км за довжини 22 км. Структура складена слабо деформованими і метаморфізованими вулканогенно-осадовими породами, що накопичувалися між 1,98 і 1,80 млрд рр. тому. Палеопротерозойські конгломерати і пісковики структури містять незвичайну асоціацію самородного золота та алмазу. Самородне золото із білокоровицьких конгломератів різноманітне як за морфологією виділень, так і за хімічним складом, що вказує на його різну природу. Переважають дрібні ксеноморфні масивні виділення золота, багато зерен пористого золота, а також зерен золота з автоепітаксійними наростами численних кристалів вторинного золота. Ці нано-мікророзмірні кристали наростів мають різну форму: від кристалографічно неправильної до ідеальних октаедричних кристалів та їхніх зростків, зокрема двійників і п’ятірників октаедрів та скелетних октаедрів. За хімічним складом золото 
дуже різне: високо- і середньопробне, сріблисте, зі значною домішкою срібла і міді, мідисте. Переважає високопробне. Часто трапляються зростки золота і кварцу. За морфологічними і хімічними особливостями золотин та мінеральними асоціаціями виділено декілька типів самородного золота: кластогенне (мало поширене), аутигенне (переважає), в тому числі біогенне і вторинне. Білокоровицькі алмази із палеопротерозойських конгломератів Волині $є$ найдавнішими за віком алмазами у Європі. За морфологією кристалів, ізотопним складом вуглецю і вмістом та станом домішок азоту вони є подібними до мантійних алмазів із кімберлітів і лампроїтів. Частина із них за ступенем агрегації домішок азоту має характеристики, типові для архейських алмазів (спокійні умови кристалізації, низький термальний градієнт в мантії). Інша частина білокоровицьких алмазів за ступенем агрегації домішок азоту має більш високотемпературний генезис, властивий протерозойським алмазам. Білокоровицькі алмази за середнім вмістом домішок азоту більше тяжіють до еклогітової мантійної асоціації, ніж до перидотитової. Інтенсивно зношені кристали алмазу можуть свідчити про їх тривале і далеке транспортування від корінного джерела до місця акумуляції. Корінними породами для білокоровицьких алмазів слід вважати кімберліти, лампроїти чи інші породи віком 1800 млн рр. чи більше. Найобгрунтованіша гіпотеза походження алмазів Білокоровицької структури - це модель субдукції. Наявні дані свідчать, що Північно-Західний регіон Українського щита був утворений між 2150 і 1980 млн рр. внаслідок безперервної субдукції океанічної літосфери та поступового наростання новоствореної континентальної кори. Значні магматичні виверження, що розпочалися біля 1815 млн рр. тому, могли бути транспортером мантійного матеріалу на поверхню, у т. ч. алмазів.

Ключові слова: самородне золото, алмаз, Білокоровицька структура, палеопротерозойські конгломерати, Український щит.

\section{В.Н. Кваснииа, Л.В. Шумлянский}

Институт геохимии, минералогии и рудообразования

им. Н.П. Семененко НАН Украины

03142, г. Киев, Украина, пр-т Акад. Палладина, 34

E-mail:vmkvas@hotmail.com; 1shumlyanskyy@yahoo.com

\section{САМОРОДНОЕ ЗОЛОТО И АЛМАЗЫ ИЗ ПАЛЕОПРОТЕРОЗОЙСКИХ ТЕРРИГЕННЫХ ПОРОД БЕЛОКОРОВИЧСКОЙ СТРУКТУРЫ, СЕВЕРО-ЗАПАДНЫЙ РАЙОН УКРАИНСКОГО ЩИТА}

Белокоровичская структура расположена в Северо-Западном районе Украинского щита. Ее ширина составляет от 2 до 6 км при протяженности 22 км. Структура сложена слабо деформированными и метаморфизованными вулканогенно-осадочными породами возрастом между 1,98 и 1,80 млрд лет. Палеопротерозойские конгломераты и песчаники структуры содержат необычную ассоциацию самородного золота и алмаза. Самородное золото из белокоровичских конгломератов разнообразно как по морфологии выделений, так и по химическому составу, что указывает на его разную природу. Преобладают мелкие ксеноморфные массивные выделения золота, много зерен пористого золота, а также зерен золота с автоэпитаксиальными наростами многочисленных кристаллов вторичного золота. Эти нано-микроразмерные кристаллы наростов имеют различную форму: от кристаллографически неправильной до идеальных октаэдрических кристаллов и их сростков, в частности двойников и пятерников октаэдров и скелетных октаэдров. По химическому составу золото очень разное: высоко- и среднепробное, серебристое, со значительной примесью серебра и меди, медистое. Преобладает высокопробное. Часто встречаются сростки золота и кварца. По морфологическим и химическим особенностям золотин и минеральным ассоциациям выделено несколько типов самородного золота: кластогенное (мало распространено), аутигенное (доминирует), в том числе биогенное и вторичное. Белокоровичские алмазы из палеопротерозойских конгломератов Волыни есть древнейшими алмазами в Европе. По морфологии кристаллов, изотопному составу углерода, содержанию и состоянию примесей азота они аналогичны мантийным алмазам из кимберлитов и лампроитов. Часть из них по степени агрегации примесей азота имеет характеристики, типичные для архейских алмазов (спокойные условия кристаллизации, низкий термальный градиент в мантии). Другая часть белокоровичских алмазов по степени агрегации примесей азота имеет более высокотемпературный генезис, присущий протерозойским алмазам. Белокоровичские алмазы по среднему содержанию примесей азота более тяготеют к эклогитовой мантийной ассоциации, чем к перидотитовой. Интенсивно изношенные кристаллы алмаза могут свидетельствовать об их длительной и дальней транспортировке от коренного источника к месту аккумуляции. Коренными породами для белокоровичских алмазов следует считать кимберлиты, лампроиты или другие породы возрастом 1800 млн лет или древнее. Наиболее обоснованная гипотеза происхождения алмазов Белокоровичской структуры - это модель субдукции. Имеющиеся данные свидетельствуют, что Северо-Западный регион Украинского щита сформировался между 2150 и 1980 млн лет вследствие непрерывной субдукции океанической литосферы и постепенного нарастания вновь созданной континентальной коры. Значительные магматические извержения, начавшиеся около 1815 млн лет назад, могли транспортировать мантийный материал на поверхность, в т. ч. алмазы.

Ключевые слова: самородное золото, алмаз, Белокоровичская структура, палеопротерозойские конгломераты, Украинский щит. 